\title{
Kiribati's Strategy in Facing the Problem of Sea Level Rise through the Kiribati Adaptation Program (KAP)
}

\author{
Maurin Astriviany \\ International Relations Department, Syarif Hidayatullah State Islamic University Jakarta - \\ Indonesia \\ E-mail: maurin.astriviany17@mhs.uinjkt.ac.id \\ Submitted: 28 April 2020 | Accepted: 30 Juni 2020
}

\begin{abstract}
Sea level rising is one of the many adverse effects of climate change. The vulnerability of the Pacific Region which generally consists of small country and island nations makes countries in the region need to be aware of the threat of sea level rising. Kiribati is one of the countries that will be most affected. Therefore, the Kiribati Adaptation Program is one of the Government's strategies that collaborated with the World Bank as the main donor party to reduce the adverse effect from sea level Rising. Divided into three phases of the program, we will see how it progresses from one phase to another. In the first phase is preparation for the program to adapt, in the second phase is the time to implement what needs to be done after reviewing the result of the first phase preparation, then in the final phase is the expansion of the program. After two phases, this third phase learned lessons from previous phases which faced few obstacles and need to be fixed before goes up to the expansion stage. Kiribati Adaptation Program will give an idea of how the strategy has been carried out by the Government of Kiribati and might become a lesson for other vulnerable countries in face the climate change effect, especially in sea level rising.
\end{abstract}

Keywords: Climate Change, Sea, Level, Rising, Kiribati, Adaptation, Program.

\begin{abstract}
Kenaikan permukaan air laut adalah salah satu dari banyaknya efek perubahan iklim. Kerentanan wilayah pasifik yang umumnya terdiri dari negara kecil dan negara kepulauan membuat negaranegara di kawasan itu perlu mewaspadai ancaman kenaikan permukaan air laut. Kiribati adalah salah satu negara yang akan paling terdampak. Maka dari itu, Kiribati Adaptation Program adalah salah satu strategi dari Pemerintah yang berkolaborasi dengan Bank Dunia sebagai pihak donor utama untuk mengurangi efek buruk dari kenaikan permukaan air laut. Terbagi menjadi tiga fase program, kita akan melihat bagaimana perkembangan dari satu fase ke fase lainnya. Pada fase pertama adalah program persiapan untuk beradaptasi, pada fase kedua adalah saat untuk mengimplementasikan apa yang perlu dilakukan setelah meninjau hasil persiapan fase pertama, kemudian pada fase terakhir di fase ketiga, adalah saat untuk perluasan program. Setelah dua fase sebelumnya, di fase ketiga ini belajar dari fase sebelumnya yang mengalami beberapa kendala dan perlu adanya perbaikan sebelum naik ke tahap ekspansi. Kiribati Adaptation Program ini akan memberikan gambaran tentang bagaimana strategi yang telah dilakukan oleh Pemerintah Kiribati dan dapat menjadi pembelajaran bagi negara-negara rentan lainnya dalam menghadapi perubahan iklim, terutama dalam kasus kenaikan air laut.
\end{abstract}

Kata Kunci: Perubahan Iklim, Kenaikan, Permukaan, Laut, Kiribati, Adaptasi, Program.

\section{PENDAHULUAN}

Climate change has been a global issue since 1979 when the first World
Climate Conference was held by the World Meteorological Organization. 
Afterward, several conferences and meetings on climate change were held again and talking more complex issues such as the greenhouse effect and sea rising level (Ratih \& Dewi, 2017).

Countries in the Pacific region are one of the regions experiencing a common problem, it is a global climate change that will have an impact on rising sea levels. Specifically, for the Pacific countries, this is a serious threat to their existence which are the smalls islands surrounded by huge waters, the Pacific Ocean (Dewi et al., 2018). Furthermore, we had to know the fact that many countries in Pacific region are consist of small islands and even according to United Nations, there are eight countries in Pacific region including Tuvalu, Vanuatu, Kiribati, Fiji Islands, Marshall Islands, Solomon Islands, Samoa, and Nauru are the most threatened countries to sinking issue due to the low elevation of islands (Jarvis, 2010).

The Republic of Kiribati is one of the countries mentioned above. This country is well-known for its natural beautiful view. Kiribati's population is around 100.000 , consists of one large island and 33 atolls (Thavat, 2013). This country was rich in phosphate, but everything was depleted by massive mined before independence. At this moment, most of Kiribati's area is sand and coral, making it difficult to do agriculture in this country, also Kiribati is very dependent on its income from fisheries and tourism. Besides, this country is also dependent on international assistance. The country of Kiribati is one of the countries with the lowest altitude from sea level. Kiribati only has an average height of fewer than two meters above sea level. Some of the areas in this country, including roads and residential areas, have begun to be submerged by the sea and most of their residents have fled to higher islands, especially around the City of Tarawa.

Kiribati could be described as an inherent climate vulnerability with limited land areas, low elevation islands, and overcrowding populations. These problems above forced the Government of Kiribati to try hard to overcome the threat. Meanwhile, Kiribati is one of the Pacific countries that is serious in its country's saving efforts. This statement could be proven by one program of the Government of Kiribati named "Kiribati Adaptation Program (KAP)" started since 2003 (Donner \& Webber, 2014) besides the others program such as National Adaptation Program for Action (NAPA), Kiribati Development Plan (KDP), National Disaster Risk Management Plan, and National Framework for Climate Change and Climate Change Adaptation. 


\section{LITERATURE REVIEW}

Picked out The Republic of Kiribati as the focus country to representation Pacific regions in terms of global impact due to climate change and environmental degradation is a wise option. Referred to other article journals and publications about the Pacific region, Kiribati is a notable country for acts of the government to prevent their country from sinking issues as written in the journal of Asia \& Pacific Policy Studies vol. 1 no. 1, Escaping a Rising Tide: Sea Level Rise and Migration in Kiribati by Kelly Wyett in 2014. The article shows that Kiribati is experiencing the environmental threat caused by climate change that will impact sea level rise. For the sake of their existence, Kiribati by its government has made projects such as donorfunded adaptation projects to limit the effects of climate change, coastal protection measures such as mangrove replantation and protect the public infrastructure, and improving water supply management. All of these projects aim to alleviate the effect of sea-level rise. So far, none of the existing sea defences have been entirely effective (Kiribati Government, 2007).

Based on that literature, we had known the Government of Kiribati has projects to save their country from sea level rising, one of the projects mentioned was a donor-funded adaptation. Kiribati itself has some of the adaptation programs, include the National Adaptation Program for Action (NAPA) and the Kiribati Adaptation Program (KAP). From two programs of Kiribati Government, the Kiribati Adaptation Program, this article would evaluate the strategy of The Government of Republic Kiribati through the Kiribati Adaptation Program (KAP) as the main focus research in this article. This program was chosen to see how their strategy and implementation of the program runs from 2003 to 2016.

On the other hand, as a comparison, the author read the article from Government of the Republic of Kiribati and United Nations of Development Program entitled Republic of Kiribati: National Adaptation Program (NAPA) published in 2007 (Government of Kiribati, 2007) for comparing what are the differences between Kiribati National Adaptation Program and Kiribati Adaptation Program, and see which program is considered more successful to help and prevent Kiribati from sinking issue and their struggle for overcoming the environmental problem that we called human and environmental securitization. 


\section{THEORETICAL FRAMEWORK Human Security}

The idea of human security began after seeing the progress of the phenomenon that occur in global development. In the report of the United Nations of Development Program (UNDP) which is oriented towards the issue of human security, in UNDP's Human Development Report in 1994 entitled "Dimensions of Human Security". There are seven categories of threats associated with human security, seventh of them are threats of personal, food, economics, politics, community, health, and environment. The report implies an international security focus should be expanded so that it does not only put attention to territorial boundaries aspect but also people's lives (United Nations Development Programme, 1994).

The environmental threat was mentioned above become one of seven threats to human security, in this case, the environment provides the basic needs of the citizen of a country or entity to live. Therefore, environment as one of the basic needs of human beings, if damaged it will become an adverse effect that occurs on the environment as a result of human activities being one of the challenges for the study of International Relations. That challenge is what political science trying to answer by beginning to shift the object of study from the traditional military issue which emphasized the focus of study to the state become broaden to human security.

These problems are also discussed in Rio plus Five United Nations Earth Summit in 1997 (Kegley and Wittkopf, 2001). Meanwhile, population growth rates are increasing and not offset by the number of resources nature exists. Meanwhile, population growth rates are increasing and not offset by the number of resources nature exists. In fact, the level of consumption continues to rise. In this case, $20 \%$ of the world's population consumes $80 \%$ of natural resources. Some countries developing which has large populations moving to a consumptive lifestyle. This is what is seen as a deep paradox of environmental safety issues (Boer, 2008).

The fact that contemporary lifestyles are sustained by the current global structure undeniably it has caused problems environment. That is what brought up the dilemma between two choices, which is to provide an opportunity on the global structure that has existed for change slowly or wait until these changes occur suddenly due to an environmental crisis (Trombetta, 2008). 


\section{Environmental Securitization}

Environmental securitization is an effort to preserve and maintain the environment, both the local environment and the biosphere environment in the Earth. Environmental issues then bring up the involved actors such as international organization, government, social movement, and many groups. The groups involved in environment securitization scheduled their activities on the political and scientific agenda which put more emphasis on science activities and non-political agenda. This agenda was made outside the political field by the research institution and scientist by pointing out the environment problems. On the other hand, the political agenda is in government zone that contains a policy-making process and decision making to overcome environmental problems. These policies are aimed to reduce human activities that might cause side effects in the form of environmental degradation as well as improve the ability of the people to adapt to climate change (Detraz and Betsill, 2009).

The environmental issue which has been getting widespread public attention in international security studies is triggered by global warming. This issue is developing in line with the paradigm shift security which previously only focused on the state become more focused on human security. Global warming threatens the continuity of environmental security and human being has encouraged the groups involved in this problem, in this concept of securitization better known as the designation of securitizing actors for scheduled real steps. They do securitize moves by echoing to the world impacts of disasters that will occur outside of human control (Trombetta, 2008).

\section{ANALSYSIS AND DISCUSSION}

\section{Initialization of the Project}

Since 2003, the Government of the Republic of Kiribati has first initialized a project named the Kiribati Adaptation Program (KAP). To succeed the program, the Government of Kiribati contributing US $\$ 0.25$ million and receives assistance from United Nations Development Program (UNDP), Least Development Country Fund (LDF), Global Facility for Disaster Reduction and Recovery (GFDRR), US\$ 0.9 million; Japan Policy and Human Resources Development (PHRD), US\$1.8; Global Environment Facility (GEF), US\$ 3 million; Australian Government, US $\$ 4.85$ million; and World Bank. This program is worth $\$ 5.5$ million U.S Dollar (World Bank, 2011). 
To support its program implementation, the Government of Kiribati cooperates with the World Bank as a donor and party to help the program's finance. But not only help in financial, but the World Bank also designed six steps that must be carried out in this program.

First, focusing on community involvement in identifying climate change during the last twenty to forty years, second is community participation in identifying climate change that currently experienced, third is involving the assessment of potential global benefits and additional costs of proposed activities, fourth is dividing the adaptation activities according to responses given by participants in the third step, in the fifth step the consultant team circulates the list of adaptations developed in the fourth step, then the last is to prioritize and determine investment in the strategy.

This program aims to overcome the environmental problem, specifically in the sea rising level, reduce the vulnerability of Kiribati from the adverse effect of climate change, and increase public awareness of the real impact of climate change that is happening in their country. The location of the project was implemented in South and North Tarawa and selected the outer islands of Kiribati.
The approach of the program was by scaling up measures from previous phases to the next phase, the program work to build resilience to climate change at community, islands, and national levels, including, (1) Protecting against coastal erosion by investing in protection such as mangroves planting and seawalls build at priority sites; (2) Improving water use and management of Water; (3) Assisting and supporting the government in monitoring, managing, and evaluating the program; Ana (4) Strengthening community and government capacity to manage the effects of climate change and natural disasters by supporting the development along with the adoption of a national Coastal Management Policy, as well as the implementation and development of locally managed adaptation plans.

Supporting education programs and facilitating the preparation also implementation of locally managed adaptation plans, a part of this program will focus on building skills within community to manage the impacts of climate change. This will be combined with efforts to strenghtening institutions, build and maintain the stronger infrastructure. The Kiribati Adaptation Program was intended to support other programs of the Government, National Adaptation Program of Action in 2007 and the 
Kiribati Development Plan that runs since 2008 to 2011 , which identify improved management of water resources and to strenghten coastal resilience as Kiribati's national priority (Development et al., 2013).

\section{Challenges}

The Republic of Kiribati is one of the most vulnerable countries in the world. Low atolls, rising population, isolated location in the Pacific Ocean, and the high cost of providing services due to the tyranny of distance make Kiribati particularly vulnerable to the impact of climate change in sea level rise and related natural disasters. Most of the infrastructure and population are concentrated along the coastline and citizens have already lost their homes as a result of the sea level rising and coastal erosion.

With prolonged droughts, freshwater supplies could be severely rationed. This means people are unable to access the water need for their survival, livelihoods, and wellbeing. Moreover, environmental degradation has an impact on the people of Kiribati. The need to act is urgently needed, In the absence of adaptation, by 2050 climate change in sea level rise could cause up to US $\$ 16$ million of economical damages in Kiribati every year, many villages on the main atoll, Tarawa and most outer islands are at risk of being largely submerged (World Bank, 2011).

\section{Kiribati Adaptation Program Phase I: Preparation}

The Kiribati Adaptation Program (KAP) first phase or preparation stage was carried out from 2003 to 2005. The purpose of this phase is to increase public awareness of the predicted impacts of climate change and promote the mainstreaming of adaptation (Prance, 2016). As a first step, Kiribati and the World Bank held the First National Consultation with Line Group and Gilbert Group, this first consultation was held between June, 23 to August 15, 2003. Furthermore, the Second National Consultation was focused on contemporary adaptation activities. Those consultations aim to design and plan projects on the aspect of climate change and sea-level rise in the seven aspects of human security challenges in Kiribati as explained above. In this phase also identified priority problems that will be implemented in the second phase.

These below are some program initiatives that will be carried out in the second phase, (1) coastal protection by planting mangrove Trees; improving the management of clean water supply; (3) strengthening the laws of coastal erosion; (4) protection of public infrastruktur; And 
residential planning (Kiribati Adaptation Program (KAP) | Climate Change, n.d.).

\section{Kiribati Adaptation Program Phase II: Pilot Implementation}

The second phase is the application of the pilotproject to develop a systematic analysis related to climate change problems and the design costeffective adaptation measures by continuing to integrate strategies and awareness of climate change impacts into operations and economic planning (White, 2007).

This stage initially consists of five components and a list of activities within each component. The five components are (1) policy, information, and planning; (2) ecosystem, physical structure, and land use; (3) capacity at the island and community level; (4) freshwater sources; and (5) project management. Activities in each component changed significantly between 2005 and 2010 (Prance, 2016).

The results of KAP II by 2011 are the Kiribati Adaptation Program II had achieved visible impacts on freshwater supply and coastal protection and sustainability including, (1) Public awareness and involvement grew significantly with the implementation of key activities, such as community training in groundwaterwell, rainwater tank maintenance, and mangroves planting undertaken by local communities; (2) The National Water Strategy was adopted in 2010 along with a National Water Strategy Master Plan. Coastal Protection Guideline was developed to ensure key infrastructure investments could withstand sea-level rise and extreme weather, as well as provide guidelines for rainwater storage and harvesting; (3) Important capacity building initiatives were undertaken with the government departments, including planning, assesment, and climate risk diagnosis; Groundwater monitoring boreholes were installed in 9 locationsand rain gauges in the outer islands have increased capacity to gather crucial climate data; (5) Water works have been completed, including a freshwater infiltration gallery to supply for over 500 people. Rainwater storage and harvesting facilities at 4 sites benefitting over 700 people; (6) Shoreline protection works were completed in first quarter of 2011. These works included planting of over 37.000 mangroves, construction of approximately 500 meters of sea walls and helping protect against coastal erosion and as a first line of defense against water contamination; Ana (7) Oversight of adaptation measures were integrated and coordinated across government. Lead office of The President was established in the first year of the program with responsibility 
to oversee adaptation. The National Adaptation Steering Committtee meets every month and attend by key ministries (World Bank, 2011).

There are obstacles happened when the Government of Kiribati conducted a review due to the project implementation faced a few obstacles.

First, the Government failed to form a Strategic National Policy and Risk Management (SNPRA) unit during the first two years of project implementation. It happened because the government did not appoint a project director and the unit remained unmanaged for eighteen months. Second, inconsistent leadership, excessive project design and weaknesses in project management were identified as the three main difficulties encountered (Prance, 2016). This finding was validated by a mid-term review by the World Bank (World Bank, 2011c). Third, lack of government leadership and frequent staff changes are identified as the main reasons Kiribati Adaptation Program in the second phase only made little progress.

As a result of the review which triggered the restructuring of the KAP program in August 2009, the World Bank requested a list of the five components of KAP II belonged with an explanation of the constraints they faced. Then, the World Bank conducts a review through World Bank staff without consulting it to the Government of Kiribati first. World Bank carried out veto right regarding adaptation activities to be continued. On the whole, activities were focused on the water sector and coastal sector and on activities that will show "tangible results in the field" (Summary \& Gef, 2005).

\section{Kiribati Adaptation Program Phase III: Expansion}

Third phase started from 2010 to 2016 as the last phase of the program. Many lessons from the previous phases are being learned in the current phase I and phase II, and these phases are informing preparation and the design of an expanded program for Climate Change Adaptation (CCA). In addition to their strategic activities for climate change adaptation, Kiribati Adaptation Program III also deals with the risk of the natural disaster which incorporates Disaster Risk Reduction (DDR) measures which in Kiribati in particular, are closely associated to climate change adaptation initiatives(Kiribati: Kiribati Adaptation Program - Phase III, n.d.). These following programs are the main activities of KAP III include, (1) Increased resilience to coastline protection in south Tarawa and management of coastal infrastructure Asset; (2) Institutional strengthening; 
(3) improving the management and use of water resources with the main sub-component of the groundwater abstraction system; increase water supply at Tungaru Hospital; water reticulation including leak detection; public awareness about water conservation; the feasibility of developing water sources in South Tarawa; and water legislation; and (4) Project management (Kiribati: Kiribati Adaptation Program - Phase III, n.d.).

\section{Kiribati Adaptation Program Result}

After over ten years of the program's implementation and expansion, the result shows the Kiribati Adaptation Program from the first phase into the third phase was progress well enough with few obstacles, but the final result will be proved after many years from the last phase ended. The result of this program was expected to be shown before 2050 and will benefit approximately 100.900 citizens of Kiribati (World Bank, 2011). By better adapting to the effects of sea level rising, Kiribati could improve better protection to its coast against storm ocean waves and improve water resources. These adaptation measures hopefully will also help Kiribati in the better management of natural disasters.

\section{CONCLUSION}

A conclusion could be drawn is that the impact of climate change, in this case, is sea level rising made Government of Kiribati aware of the adverse effect of sea-level rise, with various adaptation programs launched by the Government proves that the government of Kiribati has been aware of adverse of climate change. The Kiribati Adaptation Program was enough to grow citizen awareness of sea-level rise, but it was not enough to be said as the most successful program to suppress the impact of sea-level rise. This program itself is intended to support other programs of the government besides the National Adaptation Program of Action (NAPA) and Kiribati Development Plan (KDP) to strengthen and hopefully be able to collaborate well.

The main activity as the strategy in the program was focused on how to protect the coastline from the threat of large ocean waves, so mangrove planting activity is most often done by the government with citizens of Kiribati. Besides that, improvement in water sources also became important due to water is needed by all the people in the country.

The key to all this program's result is their genuine desire to resolve the threat. The Government initialized, the World Bank and all the parties' assistance is only helped to 
realize the government plan with financial assistance, and the citizens of Kiribati helps them to implement the program. In the end, all parties involved must participate and coordinate well to succeed in their programs and might could prevent the great adverse impact which predicted.

\section{REFERENCES}

Dewi, Putu Ratih K. (2017) "Climate Change Will Cause The Next Migrant Crisis: Studi Kasus," Jurnal Power in International Relations, vol. 2(1), pp. 82102.

Donner, S. D., \& Webber, S. (2014) "Obstacles to Climate Change Adaptation Decisions: A Case Study of Sea-Level Rise and Coastal Protection Measures in Kiribati Obstacles to Climate Change Adaptation Decisions: A Case Study of Sea-Level Rise and Coastal Protection Measures in Kiribati," Sustainability Science, 9, pp. 331-345. Doi: https://doi.org/10.1007/s11625-0140242-z (Accessed: 7 April 2020).

Elisabeth, D., Apresian, Stanislaus R., Omega, W.V., Pangestika, F.W., Gianni, A. (2018 Kolaborasi Antara Indonesia dan Negara-Negara Kepulauan Pasifik dalam Menghadapi Tantangan Lingkungan. Bandung: LPPM Universitas Katholik Parahyangan.

GCCA, PSIS - SPC. (2013) Review of Mainstreaming of Climate Change Into National Plans And Policies: Kiribati. Kiribati: GCCA, PSIS - SPC.

Government of Kiribati. (2007) Republic of Kiribati National Adaptation Program of Action (NAPA). Tarawa: Environment and Conservation Division, Ministry Of Environment, Land, And Agricultural Development.
Jarvis, R. (2010) "Sinking Nations and Climate Change Adaptation Strategies", Seattle Journal for Social Justice, Vol. 9(1), pp. 447-486.

Prance, F. (2016) Institutions and Values: Climate Change Adaptation Mainstreaming Implementation in Kiribati. Australia: The University of Adelaide, pp. 1-10.

Republic of Kiribati. (n.d) Kiribati: Kiribati Adaptation Program - Phase II (Online). Available at: https://www.worldbank.org/en/results /2012/04/16/kiribati-adaptationprogram-phase-2 (Accessed: 7 April 2020).

Republic of Kiribati (n.d) Kiribati Adaptation Program (KAP), Climate Change (Online). Available at: http:/ /www.climate.gov.ki/kiribatiadaptation-program/ (Accessed: 7 April 2020).

Thavat, M. (2013) A Spotlight on Kiribati, Australia's Apprach: Matching Global Change Commitments With Immediate Need and Capacity. Australia: Advancing Integration Series, pp. 1-9.

The World Bank. (2011) Kiribati: Kiribati Adaptation Program - Phase III (Online). Available at: https://www.worldbank.org/en/results /2011/09/15/kiribati-adaptationprogram-phase-3 (Accessed: 7 April 2020).

Trombetta, M. J. (2008). Environmental security and climate change: Analysing the discourse. Cambridge Review of International Affairs, Vol. 21(4), pp. 585602. Doi:

https://doi.org/10.1080/09557570802 452920 (Accessed: 7 April 2020).

UNDP. (1994) Human Development Report: New Dimension of Human Security. New York: Oxford University Press.

White, Ian. (2007) Republic of Kiribati Pilot Project: A Whole-of-Government Approach to Water Policy and Planning. Australia: Australian National University. 
Wilde, J.H. (2008) Speaking or Doing Human Security? in den Boer, Monica \& Jaap de Wilde (ed). The Viability of Human Security. Amsterdam: Amsterdam University Press. 